The Geneva Papers on Risk and Insurance, 22 (No. 85, October 1997), 477-495

\title{
Some Thoughts on Sustainability, Insurability and Insurance
}

\author{
by Walter R. Stahel*
}

\section{Summary}

There are clear indications that the present "old" industrial economy needs a serious adjustment to become compatible with the aims of a sustainable society. The main issues involved are the time factor, resource productivity and socio-cultural ecology.

- the time factor: sustainability is a long-term societal vision concerned with the stewardship of natural resources and assets in order to safeguard the opportunities and choices of future generations. The industrial economy is often limited to a short-term optimization of throughput in monetary terms. Changing course towards a more sustainable society means to introduce the indeterministic time factor into economic thinking, which again implies an indeterministic vision of economics and the capability to deal with uncertainty.

- resource productivity: in the present industrial economy, micro- and macro-economic success is directly coupled with resource flows (flows of matter and energy), due to its linear structure. The per capita resource consumption of this system cannot be generalized to the less developed countries without a world system collapse. In order to become sustainable, industrial economies must operate at a much higher level of resource productivity, i.e. be able to produce the same utilization value out of a greatly reduced resource throughput ${ }^{1}$. This change of course can be achieved by decoupling economic success and resource throughput - one way to do this is to change to a service economy, in which the measure of success refers to the performance of assets (stocks) instead of flows, and to stock utilization (Giarini and Stahel, 1989/93).

\footnotetext{
* Director of the 'The Product-Life Institute / Institut de la Durée', Geneva.

${ }^{1}$ It has been calculated that industrialized countries need to reduce their resource flows by a factor of 10 , in order to enable the Less Developed Countries to multiply their per capita resource input within a sustainable level of World resource flows (Carnoules declaration of the Factor 10 club).
} 
- social and cultural ecology: the industrial economy has been largely technology-focused, using monetarized values as its main yardstick. A sustainable society is result-focused and based on social and cultural values (non-monetary assets), as well as economic values. Changing course towards a more sustainable society means to take into account social and cultural factors as peers to economic ones. The role of money still needs to be better understood and accepted, but the creation of wealth will increasingly depend on nonmonetarized assets and activities.

This adaptation corresponds to a fundamental change, or paradigm shift, as the objectives of a service economy are quite different from those of an industrial economy: to maintain or increase total wealth and welfare, i.e. the monetary and non-monetary assets of society, over long periods of time. Its focal point is the optimization of utilization, i.e. of the performance and the results achieved with goods, rather than the goods themselves. The central notion of economic value in the service economy is the value of utilization over time, in contrast to the momentary value of exchange at the POS (point of sale) in the industrial economy (the added value system is only a subsystem of a larger economic concept). Similarly, quality in the service economy is defined as long-term optimization of system functioning, not as a momentary quality at the POS.

For this paradigm shift towards a sustainable society, new tools are needed to control liabilities and simultaneously speed up innovation in commercial and technical areas, and to provide benchmarks for assessing new solutions. Insurance is maybe the only quick way to provide free-market safety nets for real innovation, and the concept of insurability is probably the most efficient free market assessment tool to chose between different options. This means that insurance and insurability could play a key role in the transition towards sustainability. But as a higher resource productivity also induces reduced costs (the "double dividend" of reduced resource procurement costs and reduced waste costs), insurance could even be the hidden joker to achieve a higher and greener economic competitiveness.

Today, only few people in insurance, politics or the economy are aware of these links and opportunities, which this paper will try to show.

\section{Introduction}

The term "sustainability" stands for an economy with a long-term objective which lives exclusively from its interests, while maintaining or increasing its capital (see box 1 for details). The term "insurability" stands for methods to assess risks and influence their technical fundamentals so that the risks can be covered efficiently on the insurance market. The threshold of insurability constitutes therefore the boundaries within which the private market operates.

A long-term vision is an integral part of sustainability, similar to the long-term outlook of the insurance sector. This contrasts with the still dominant short-term interests of many industry projects. Sustainability also includes elements of caring (for existing wealth and riches), and of maintaining existing performance, which again can be found in insurance philosophy, such as the duty of the insured to take action to limit losses where possible. 
The notion of the precautionary principle, which made its first political appearance in the declaration of the 1992 UN conference at Rio, promotes the objective of giving loss prevention preference over cure (at least for non-renewable natural assets), similarly to the principles of risk management.

The concept of sustainability is a microcosm of the concept of insurance, as it incorporates aspects of both pure (and thus insurable) risks, as well as of entrepreneurial (and thus uninsurable) risks. Both include monetary (economic) issues as well as nonmonetary (social, natural and cultural) ones, within a context of a high and interlinked complexity and vulnerability.

\section{The evolution of the links between insurance and sustainability}

\subsection{The early focus on protecting "people and nature": insurance as a co-player to industry}

In the past, the impact of the insurance sector on sustainability was mainly through the application of strategies of risk management and loss prevention to problems of safety and health $(\mathrm{S} \& \mathrm{H})$ at the workplace. The industrial sectors concerned were the most dangerous ones, e.g. the mining and chemical industries, manufacturers of gunpowder such as DuPont de Nemours, and nuclear power stations. After each catastrophe, the risk managers introduce new approaches to make sure that the catastrophe could not repeat itself; the analysis of the Flixbourough explosion, for example, led to a change in production processes, from a batch to a flow process in order to reduce the amount of chemicals in any part of the process from one ton to one kilogram, but also to the establishment of a British center where all minor mishaps and potentially serious incidents had to be reported, in order to "read the signs" and try to prevent disasters by eliminating similar danger spots throughout the UK chemical industry.

Only since the mid 1980 s has the attention of the S\&H managers in industry started to include issues of environmental protection, such as nature conservation and the prevention of pollution and wastes which affect areas outside the factory gates. This later development was facilitated by the fact that loss prevention and waste prevention issues are closely related, and that many existing risk management strategies could easily be "translated" into the environmental context. In many companies, the Safety \& Health departments logically became SHE (safety, health and environment) departments. Voluntary industry-wide agreements, such as the "responsible care" programme in the chemical industry, were developed in order to minimize hazards to the environment, but also the danger that a black sheep could give the whole sector a bad image. The industryinduced pressure on governments to ban $\mathrm{CFCs}^{2}$ is an early child of this period.

The inherent problem of this period was that "protecting the environment costs money". There was therefore a permanent danger of a collision of interests between economic actors and environmentalists. In this situation, Nation-States had to take control in order to protect the environment, through "command and control"-legislation on issues of limiting toxicity levels and environmental impairment. layer.

${ }^{2} \mathrm{CFC}$ are chlorofluorocarbon chemicals which are the main culprits for destroying the ozone 


\section{Box 1: The pillars of a sustainable society}

The concept of Sustainability is based on techno-economic and socio-cultural pillars, each of which is essential for the "survival" of the natural eco-system - of which mankind is part - on Earth. It is of no use to argue on priorities, or speculate on which of these pillars can be lost first; society cannot take the risk of losing any single one of them:

1. nature conservation, or the eco-support system for life on the planet. This pillar contains global aspects (e.g. biodiversity, oceans and the atmosphere as global commons), as well as regional ones (the carrying capacity of nature with regard to populations and their lifestyle, e.g. drinking water, arable land).

2. health and safety (or non-toxicity; qualitative): a danger mainly to the health of people and animals, resulting increasingly of man's own activities (e.g. the accumulation of toxic substances in the environment: DDT, mercury, Thalidomide).

\section{The first ceasure: from nature conservation to increased competitiveness}

3. reduced flows of resources, or higher resource productivity (quantitative, e.g. $\mathrm{CO}_{2}$, material flows): a potential of radical change for the planet (towards a reacidification and/or climate change), and thus a threat to man's life on Earth. Also a factor of disequilibrium between economies in North and South.

The second ceasure: from a sustainable economy to a sustainable society.

The "Quest for a Sustainable Society", however, must be much broader and include the longevity and sustainability of our non-techno-economic structures:

4. social ecology, the fabric of societal structures, including issues such as democracy, peace and human rights, employment and social integration, security and safety. Accepting the global commons, overcoming the "prisoners' dilemma", sharing and caring, the barter economy.

5. cultural ecology includes education and knowledge, ethics and culture, as well as values of national heritage at the level of the individual, the corporation and the State: "Show to others that you are able to care, by looking after e.g. your car, your house (instead of buying a new one)"; "Good engineering and industrial design has always also been ecologically responsible"; "Only people, not robots, can permanently improve product quality"; "Waste is inefficient and therefore un-japanese".

Source: Stahel, Walter R. (1997) The Service Economy; "Wealth Without Resource Consumption?"; in: Philosophical Transactions, Royal Society London, A, no. 355, p. $1309-1319$. 


\subsection{The present focus on resource productivity: insurance as the key player for increased economic competitiveness}

With the introduction of the term "sustainability", first in the 1970s in academic circles, and then its generalization at the UN conference in Rio in 1992, "the environment" took on a much larger, and also more complex, meaning. The term "sustainability" (Nachhaltigkeit) was first used 200 years ago by Prussian foresters and stood for the longterm management of forests in order to maximize the "interests" (in the form of timber, game, etc) while maintaining or increasing the "capital" (the forest) at the same time. This definition, which includes already the idea of "resource management" that today starts to dominate over the traditional "nature conservation", spread to forestry management in other countries including the USA.

In the late 1980s, the idea gained ground that protecting the environment was not enough to guarantee the long-term future of "spaceship Earth", and that only the transformation of the modern industrial economy into a more sustainable (service) economy could lead to a sustainable future. At the basis of this reasoning was the recognition that the rate of consumption of non-renewable resources (energy, water, air and materials) in the industrialized countries was the major challenge, as the $20 \%$ of the world population in industrial countries consumes $80 \%$ of all resources. A more balanced resource use can only be achieved if the OECD countries develop innovative new solutions for the needs of the industrialized world.

Let us take $\mathrm{CO}_{2}$-emissions as an example, $80 \%$ of which originate from industrialized countries: $\mathrm{CO}_{2}$-emissions are not a problem of toxicity, and cannot be solved by the traditional "command and control"-approach of Nation-States, but only by inventing and commercializing new technologies that do not use fossil energies. This constitutes a paradigm shift, from the "nanograms of toxicology" to the "magatonnes of resource consumption", and from State-driven "command and control"-policies to innovationdriven private sector initiatives (see the first ceasure in box 3 ).

Insurance can now take a proactive key role in speeding up this paradigm shift by providing new insurance products that replace legislation and technical standards. What is needed is the availability of probability-based financial safety nets that can deal with the complexity of modern technology and account for the unforeseeable risks inherent in any novel solutions. State safety rules (legislation, regulation and technical standards) are extremely slow, and based on past experience - inappropriate for the forward-looking approach needed in a paradigm shift.

As a higher resource productivity (or dematerialization) pays a double dividend (reduced procurement costs and reduced waste disposal costs, in an economy with closed material and liability loops), this development towards a dematerialized economy will result in a higher competitiveness of enterprises and of nations. Insurance might even be the only economic player able to rapidly and efficiently promote innovation towards a higher sustainability! 


\subsection{The future focus on social and cultural ecology: insurance protecting its very foundations}

A sustainable society strongly depends on cultural values; this even shows up in the definition of "sustainability". Native Americans - referred to as "Indians" by Christopher Columbus - used a "Southern" positive approach: "everything you do should have a positive impact on the next seven generations". The "Northern" liability-based thinking of the industrial countries shows up in the definition of the 1992 Rio conference: "today's population should only use as many resources to fulfill their needs, as to leave enough resources for future generations to fulfill their needs" (think about it - the ultimate forecasting riddle!).

Perhaps the future key issue for insurance, however, is the common denominator of sustainability and insurance: the need for a stable social fabric (the second ceasure in boxes 1 and 3 ). This need is partly based on the long-term outlook: industrial companies may sometimes survive by making a "quick buck", but neither nature nor insurance will. Social and cultural ecology are a precondition for a sustainable society; if the vision of sustainability is limited to the efforts of creating a more ecological technology (toxicology and resource productivity), they may have been in vain, as social upheaval does not care for nature conservation, toxicology or resource productivity. Catastrophes of all kinds (technical, natural or warfare) can serve as examples for this (see box 2). Insurance therefore has a self-interest to actively promote and foster the speeding up of the transfer from an industrial economy, the success of which is based on resource throughput and manufacturing, towards a sustainable society, the success of which is based on services, the management of existing assets, technologies that enable dematerialized performance to fulfill needs, and a functioning social and cultural fabric (in short: a service economy) (see Giarini/Stahel 1989/1993).

\section{The insurability of risks as an economic benchmark for limiting the risk exposure of society to technology: a future role for risk assessment}

Sustainability suffers in each catastrophe (box 2). In the case of technical risks, insurance can provide scientifically justified yardsticks for the choice between competing technologies, based on the economic feasibility of loss prevention and risks reduction measures v. clean-up and replacement costs. Only insurance can give a guarantee that it will not be the State that picks up the bill if things go wrong, or if the risk assessment calculations were incorrect, as was the case of e.g. the insurance cover for underground hydrocarbon storage tanks.

Students of economics listen to lectures about the advantages of "economy of scale", without ever hearing a lecture on the "dis-economy of risk" that follows like a shadow the "economy of scale", but is differentiated from it by a short-term v. a long-term view. In many cases, the "dis-economy of risk" is part of the entrepreneurial risks and thus not submitted to the judgement of insurability. Concentrating $90 \%$ of the world production capacity for colour LCD, a key component for portable computers, in one factory in Kobe did make "economy of scale"-sense, at least until the Hanshin earthquake destroyed the factory, led to a worldwide shortage of this component, and resulted in substantial damages and a huge loss of income for the "efficient" manufacturer. 


\section{Box 2: The Impact of the Great Hanshin Earthquake on sustainability}

On Jan 17, 1995, within 10 seconds, an earthquake killed over 6'000 people and fully destroyed 100 '000 buildings. This resulted in 20 million tons of disaster waste (the equivalent of 9 years total waste from the same area). In order to limit the risk of diseases, demolition and reconstruction had to start quickly, which meant disposing of the waste rapidly. The only way to do this was to burn it in the open air, on the beach. This resulted in $80^{\prime} 000$ tons of ash (plus 200 grams of dioxin).

In comparison, the 17 year war in Lebanon produced 5 million tons of waste, the 1993 earthquake in Los Angeles produced only 2 million tons.

The disaster waste included the structures and contents of buildings, including asbestos and organic solvents. Among the hazardous materials included in the waste was methyl methacrylate, the maximum level of which reached 70 times the level allowed by WHO standards. The figures do not include the dust from the demolition of buildings and structures, which took place without any water spraying, as all the pipes had been damaged! Furthermore, huge quantities of LPG (liquified petroleum gas) escaped, fortunately without major explosions. It is estimated that about 110 tons of CFCs escaped or were disposed of (incinerated) with the waste.

If the same earthquake had hit Tokyo, the potential damage could have reached 1,6 trillion US\$ in direct damages. In addition, losses under business interruption could have reached the same figure, bringing the potential total damages to more than three trillion US dollars, if.

Source: Mr Isamu Yamamoto, Chief Consultant, The Sumitomo Marine Research Institute, Inc., at the UNEP Conference on implementing environmental commitment in the insurance industry. London 1996.

In cases where "economies of scale" are part of insurable risks, insurance has a chance of proving the "dis-economies of risk". Fifteen years ago, the shipping industry's dream of moving from ULCCs, the ultra large crude carriers with a capacity of 500'000 dwt, to tankers with 1 million dwt capacity, ended abruptly when it was shown that the increase in insurance premium, strongly influenced by the costs of a potential (eco) catastrophe, was higher than the relative saving in crew costs. As a result, the 1 million dwt tanker were never built - and today, most of the ULCCs have been scrapped, as smaller tankers offer a higher flexibility in use which makes more business sense, even if their operating costs are slightly higher than those of a ULCC.

In one case, industry has discovered the advantages of dis-economies of risk, possibly to the detriment of society. A series of accidents at Hoechst, the German chemical company, led in the German market to the limitation of EIL (environmental impairment liability) cover under general business liability contracts to a maximum of 30 million DM per company. In the wake of this, most chemical companies subcontracted the transport 
(and the transport liability) of dangerous goods to less qualified, often small independent haulage companies.

In general, it can be said that mandatory insurance of risks and liabilities greatly enhances incentives for loss prevention by economic actors (and replaces a disaster management by the State when things go wrong), and could provide economic reasons against the globalization of the economy. Solar energy, for example, would have been developed and commercialized at a much quicker pace had States not subsidized all phases of nuclear energy and imposed an artificial liability limit and an exclusion clause for claims from abroad on nuclear liability. Exceptions to the principle of "insurance as preferred free market safety-net" should need to be justified, and only be considered in cases of the precautionary principle, such as the non-availability of flood insurance in the Netherlands (to drive the idea home that engineers and proper maintenance, not insurance, can prevent damages), or in the non-insurance of losses that the human operator can prevent (such as rearend collisions in driving which are no longer insured in California).

Quality standards and the defense of using "state-of-the-art-technology" today often replace self-responsibility of economic actors and act as disincentives for inventions and innovations. But quality standards can be imposed in different ways: The periodic quality control of car exhaust fumes is a very European solution, which puts the burden of maintenance liability and cost on the car owner. The U.S. quality control of exhaust fumes is based on random checks of cars in the street, and the manufacturers' obligation to recall and correct, at his expense, all vehicles of any type that is found to violate antipollution standards.

\section{A unique new role for insurance to promote sustainability}

In the mid 90s, sustainability has developed into a direction which opens new opportunities for the concept of "insurability of risk", and thus for insurance, to contribute directly towards a higher sustainability (the first ceasure in boxes 1: from nature conservation to increased competitiveness).

\subsection{Fostering the efforts by industry towards a higher resource productivity}

Risk management and loss prevention are the common denominators of the five pillars of sustainability: every catastrophe, natural or technical, tends to have a disastrous effect on all five pillars. An example is given in Box 2. Loss prevention is therefore still one of the most efficient holistic strategy towards a higher sustainability.

An analysis of the evolution of the five pillars of sustainability, from one pillar to the next, allows the identification of two ceasures with regard to actors and issues involved (see box 3).

The first ceasure became apparent when attention started to shift "from nanograms to megatons". i.e. from the second pillar of "health and safety" to the third pillar of "resource productivity". Until then, biologists and chemists had been the driving force, acting through national "command and control"-legislations in order to conserve nature and limit negative effects on human health, in the name of Nation-States. This development caused differences between legislation in different countries and often a higher economic cost. It also led to a controversial, sometimes even belligerent, attitude 
Box 3: Key actors and issues in each of the five pillars of sustainability

\begin{tabular}{|c|c|c|c|c|}
\hline \multirow{2}{*}{$\begin{array}{l}\text { pillars of } \\
\text { sustainability } \\
\text { (values) }\end{array}$} & \multicolumn{3}{|l|}{ actors which can } & \multirow{2}{*}{$\begin{array}{l}\text { monetary } \\
\text { costs and } \\
\text { benefits }\end{array}$} \\
\hline & $\begin{array}{l}\text { define } \\
\text { objectives }\end{array}$ & $\begin{array}{l}\text { identify } \\
\text { solutions }\end{array}$ & $\begin{array}{l}\text { deal with } \\
\text { abuse }\end{array}$ & \\
\hline $\begin{array}{l}1 \text { nature } \\
\text { conservation } \\
\text { (natural assets) }\end{array}$ & $\begin{array}{l}\text { States, } \\
\text { precautionary } \\
\text { legislation } \\
\text { (asset } \\
\text { management) }\end{array}$ & $\begin{array}{l}\text { nature itself } \\
\text { (biologists), } \\
\text { "command } \\
\text { and control" }\end{array}$ & $\begin{array}{l}\text { precaution } \\
\text { (avoid } \\
\text { "non-repairable" } \\
\text { damages) }\end{array}$ & $\begin{array}{l}\text { lost opportu- } \\
\text { nity costs }\end{array}$ \\
\hline $\begin{array}{l}2 \text { safety and } \\
\text { health } \\
\text { (non- toxicity) }\end{array}$ & $\begin{array}{l}\text { States, } \\
\text { legislation to } \\
\text { limit damages } \\
\text { (after scientific } \\
\text { proof of } \\
\text { damages) }\end{array}$ & $\begin{array}{l}\text { scientists } \\
\text { (chemists } \\
\text { and M.D.s), } \\
\text { "command } \\
\text { and control" }\end{array}$ & $\begin{array}{l}\text { financial } \\
\text { compensation } \\
\text { to victims, } \\
\text { fines and prison } \\
\text { sentences }\end{array}$ & $\begin{array}{l}\text { additional } \\
\text { costs }\end{array}$ \\
\hline
\end{tabular}

first ceasure: from nature conservation to increased competitiveness

\begin{tabular}{|c|c|c|c|c|}
\hline \multirow{3}{*}{$\begin{array}{l}3 \text { higher } \\
\text { resource } \\
\text { productivity }\end{array}$} & consumers & sufficiency & $\begin{array}{l}\text { change } \\
\text { supplier }\end{array}$ & savings \\
\hline & enterprises & $\begin{array}{l}\text { better business } \\
\text { solutions } \\
\text { through } \\
\text { innovation }\end{array}$ & $\begin{array}{l}\text { free-market finan- } \\
\text { cial safety-nets, } \\
\text { e.g. insurance }\end{array}$ & $\begin{array}{l}\text { savings in } \\
\text { procurement } \\
\text { and waste } \\
\text { disposal }\end{array}$ \\
\hline & States & $\begin{array}{l}\text { new industrial } \\
\text { policy based on } \\
\text { incentives for } \\
\text { innovation and } \\
\text { sustainability }\end{array}$ & & $\begin{array}{l}\text { savings } \\
\text { through lean } \\
\text { administra- } \\
\text { tion and risk } \\
\text { transfer }\end{array}$ \\
\hline \multicolumn{5}{|c|}{ second ceasure: from a sustainable economy to a sustainable society } \\
\hline $\begin{array}{l}4 \text { social ecology } \\
\text { (invisible fabric) }\end{array}$ & $\begin{array}{l}\text { parents, } \\
\text { communities, } \\
\text { corporations, } \\
\text { States }\end{array}$ & $\begin{array}{l}\text { education } \\
\text { and knowledge }\end{array}$ & $\begin{array}{l}\text { feed-back } \\
\text { loops to peer } \\
\text { groups } \\
\text { (punishment) }\end{array}$ & $\begin{array}{l}\text { savings in } \\
\text { social costs }\end{array}$ \\
\hline $\begin{array}{l}\overline{5 \text { cultural }} \\
\text { ecology }\end{array}$ & $\begin{array}{l}\text { individuals, } \\
\text { corporations, } \\
\text { States }\end{array}$ & $\begin{array}{l}\text { education and } \\
\text { ethics }\end{array}$ & $? ? ?$ & $\begin{array}{l}\text { savings in } \\
\text { social costs }\end{array}$ \\
\hline
\end{tabular}

Source: Stahel, Walter R. (1997) The Service economy: "wealth without resource consumption?"; in: Philosophical Transactions A, The Royal Society London, 355, p. 1309-1319. 
between "environment" and "industry". The role of insurance was mostly a reactive one, paying for bodily harm and health impairment, as well as clean-up costs, after things had gone wrong (e.g. Seveso, oil spills, asbestos) and only if the faulty party had insurance cover. If the insurance cover was insufficient, or if the sums paid out in compensation did not correspond to what the people affected had expected (as is often the case in e.g. natural disasters), the image of insurance as a whole suffered in the eyes of the public at large: head or tail, insurance loses.

A higher resource productivity entails higher economic and ecologic benefits. Under the slogan "earning more money while buying less resources", managers are learning to produce a higher revenue for their companies while constantly reducing the necessary input of resources (energy, materials, water and land) - and often using less fixed capital. This challenge is there for engineers and industrial designers, marketeers and business people to be picked up through innovation towards a substantial increase in resource productivity - the aim being an increase by a factor ten (equal to a dematerialization by $90 \%$ ). The traditional guardians of "command and control" are no longer needed in achieving a higher resource productivity.

The encouragement of an increased voluntary selfresponsibility of economic actors, supported by some kind of guarantees, as an alternative to mandatory standards and regulatory guidelines, could become a key factor in the race towards an increased competitiveness of the economy of industrialized countries, fostering innovation, speeding up the time-to-market of innovations and promoting innovative (non-linear) technological development. And the role of insurance cover for these new risk takers could become a key factor for the success of the entrepreneurs.

Insurance can now take a new role as an proactive key actor, with a positive image in society of fostering progress towards sustainability! "Innovation by enterprises" and "an industrial policy to promote sustainability" are the key political and corporate strategies to increase resource productivity - not only towards a more sustainable society, but also towards a higher economic competitiveness! This corresponds to a fundamental change in political thinking, from ecology $\mathbf{v}$. economy towards an ecological economy, and from State $v$. industry towards joint State-enterprise innovation commitments, in order to remove obstacles which hinder, and create incentives which foster, innovation for more sustainable solutions.

\subsection{Insurance as a flexible safety-net that speeds up the commercialization of innovation}

The State still has to protect the health of people and the integrity of nature, but in addition now has to speed up innovation for a higher resource productivity - and this can best be done through incentives to innovate, and through flexible free market safety-nets, such as insurance (e.g. for environmental impairment liability and product liability) instead of laws and standards! In order to provide a level playing field, these safety-nets may have to be mandatory - if not, the State may again become the "insurer without premium" of catastrophic risks. The biggest mistake the State can make would be to get directly involved itself. This would be a slow and inefficient way to promote change, and might greatly limit economic competitiveness. The State might still be tempted to do so as it would enable it (or rather the civil servants) to retain power, to stay in control - ignoring 
the fact that there is no control of a creative chaos, only efficient safety barriers and safety nets.

At a time when tax authorities increasingly leave it to FASB $^{3}$ and the stock exchange to define valid accounting guidelines (because banks and stock exchanges have a prospectus liability, and therefore a self-interest to verify the figures they are given before they pass them on to the consumer), the State should define the aim of, but not the strategies to, a higher resource productivity. The State should also make sure that the economic actors which innovate get rewarded and promoted, and that those (or their safety-net) caught cheating will have to pay up. By doing this, the State itself would also profit in becoming considerably leaner and more efficient.

Such a new industrial policy would introduce the principle of "insurability (of risk)" into the economy as a guiding principle to chose between possible technologies, present and future. It would also speed up the transition towards a higher sustainability in combination with a higher economic competitiveness, and give an economic incentive to applications of the precautionary principle. "An adequate understanding of, and efficient policy for, the developent of the private insurance sector is the key to success for the policies of governments in the sectors concerned" (Garini, 1997).

But (as you know, there is always a "but") the State would lose control over this development, which would evolve chaotically, in a hardly foreseeable way, without certainty. As the environment protection agencies in most countries are staffed by chemists and biologists from the earlier command and control period of nature conservation, they will not see such a development with a friendly eye. The fact that they are still needed for the supervision of issues concerning the protection of nature and health might not console them with the overall loss of power involved in this first ceasure from nature conservation to competitiveness.

Insurance with all its different forms, however, would move into the center of attention, as insurance cover would be needed to bolster the unwanted and unknown negative effects of innovation that might appear in the future.

A case in point that insurance can efficiently replace technical (State) standards as safety-nets for unknown risks is the example of the "Siemens Fax 550". In 1992, Siemens commercialized the first multifunctional electronic office machine (the Fax 550) which fulfilled the functions of a fax, scanner, copier and printer all in one small machine. Multifunctional goods are one of the keys to a higher resource productivity (box 4, ecoproducts), and this was a revolutionary concept that meant lower costs to consumers and higher benefits to Siemens. Or would have meant, if Siemens had been allowed to sell the product worldwide. Sales outside Germany were blocked off because there is an international agreement aimed at protecting consumers which states that an electronic good can only be sold if there is an international technical standard for it - which by definition there was none, as this was the first machine of its kind. It took five years to develop such a standard, by which time (1996) all competitors of Siemens had a similar

${ }^{3}$ FASB Financial Accounting Standards Board, the non-government body that makes America's accounting rules. 
machine on the market. The competititve advantage of Siemens was lost due to the inflexibility of the State safety-net!

This multifunctional fax did not use any revolutionary technology or present any unknown risks to society. But it did present the risk of a precedent to the international standards community. If an (unlimited) insurance cover would have been accepted as equivalent protection to a technical standard, Siemens would have taken all its competitors by surprise, and possibly a huge share of the World market. As it happens, Siemens took everybody by surprise, but without reaping the economic benefits.

\subsection{New opportunities for insurance in resource efficiency market niches}

A higher resource productivity can be achieved by a number of strategies, which are listed in box 4 in decreasing order of impact. The message in a nutshell is as follows: the most efficient strategies are those of sufficiency or "zero-options": lying in your hammock is the environmentally most efficient way to mow your lawn (which in any case should be a meadow with a high biodiversity instead of a lawn). But if you really want to cut the grass, have it done through a grasscutter-service (gardener); if this is too expensive, borrow the tool or machine from your neighbour. If that is not feasible, buy a high-quality tool and use it forever, with appropriate maintenance and care.

Sufficiency options are a strategy for higher sustainability and "wealth without resource consumption" that is, however, only of economic interest in the context of a service economy. Witness a hotel: by offering its guests to "save the environment" by reusing towels for several days, the hotel does indeed reduce the consumption of water, detergents and wear and tear of washing machines. But it also reduces its laundry costs and extends the useful life of towels and washing machines, thus increasing its profit margin. Zero-options, or sufficiency, are among the most ecologically efficient solutions, and they offer the highest monetary rewards in a service economy.

Successful examples of zero-options also exist in the insurance sector. The exclusion of rearend collisions in California car insurance contracts makes it clear to the driver that he can avoid this risk by keeping a large distance to the car in front - and the effect is visible! On German motorways, it is equally visible that rearend collisions are covered by insurance, never mind how closely you follow the car in front of you! The non-availability of flood insurance in the Netherlands offers another example of a zero-options: it makes it clear to all Dutch that only the engineers in charge of the dykes can protect the one third of the country that lies below sea level - flood insurance cannot prevent a disastrous flood, proficient engineers possibly can, through the construction, constant supervision and maintenance of a system of dykes.

The second set of strategies of "system solutions" (box 4) pose a challenge for insurers. These strategies rely on the principle of "selling performance instead of selling goods", for example "selling individual mobility instead of cars", by providing a taxi or limousine service, by renting cars, or even by providing a virtual mobility (internet) instead of physical mobility. In many cases, this means that the goods manufacturer becomes a "fleet manager" (of a fleet of goods), thus moving from the industrial economy to the service economy, with an increased liability for "customer satisfaction" rather than the traditional liability for the manufacturing quality of the goods (see (Giarini/Stahel, 


\section{Box 4: Demand and supply strategies for a higher resource productivity}

\begin{tabular}{lll}
\hline $\begin{array}{l}\text { Increased resource } \\
\text { productivity through: }\end{array}$ & $\begin{array}{l}\text { Type of strategies: } \\
\text { closing the material loops } \\
\text { technical strategies }\end{array}$ & $\begin{array}{l}\text { closing the liability loops } \\
\text { commercial/marketing strategies }\end{array}$ \\
\hline sufficiency options & $\begin{array}{l}\text { near ZERO-OPTIONS } \\
\text { ploughing at night }\end{array}$ & $\begin{array}{l}\text { ZERO-OPTIONS } \\
\text { towels in hotels } \\
\text { car insurance in California }\end{array}$ \\
$\begin{array}{l}\text { system solutions } \\
\text { reducing volume and } \\
\text { speed of the resource } \\
\text { flow }\end{array}$ & $\begin{array}{l}\text { SYSTEM-SOLUTIONS } \\
\text { Krauss-Maffei PTS plane } \\
\text { transport system, } \\
\text { skin solutions, accessibility. }\end{array}$ & $\begin{array}{l}\text { SYSTEMIC SOLUTIONS } \\
\text { lighthouses, } \\
\text { selling results instead of goods, } \\
\text { selling services instead of goods. }\end{array}$ \\
\hline
\end{tabular}

\section{more intensive}

utilization of goods reducing the volume of the resource flow:

ECO-PRODUCTS

dematerialized goods, multifunctional goods.
ECO-MARKETING

shared utilization of goods, selling utilization instead of goods

\section{longer utilization}

of goods

reducing the speed of the resource flow:

\author{
RE-MANUFACTURING \\ long-life goods, \\ service-life extension of \\ goods and of components, \\ new products from waste.
}

\author{
RE-MARKETING \\ dis-curement services, \\ away-grading of goods, \\ marketing of fashion upgrades for \\ goods in the market.
}

Source: adapted from: Giarini, Orio and Stahel, Walter R. (1989/1993) The Limits to Certainty, facing risks in the new Service Economy; Kluwer Academic Publishers, Dordrecht, Boston.

1989/1993) for the repercussions of this change). Selling performance instead of products is a more sustainable strategy because it includes an intensive utilization of the goods, as well as a product stewardship over the total life-cycle of a product "from cradle back to cradle". System solutions have found many business applications in the inter-company market, such as the B.O./B.O.T.-concept (build-operate(-transfer), e.g. the channel tunnel), operational leasing of aircraft, the charter of ships, office blocks for rent; they only start to make inroads into the consumer markets (e.g. rental of notebooks, mobile phones at airports).

The strategies of system solutions also open new business opportunities for service companies: Banks and insurance companies have started to act as car fleet managers, often through subsidiaries. Insurers can also extend the validity of the individual contracts to cover hired cars, as is the case in the UK, and thus improve their business. If they do not, insurers may, however, lose a multitude of individual contracts to the fleet managers 
(which may use self-insurance or their own captive). In general, the first mover wins; once people have given up owning cars, it will be difficult to sell them hire car cover, as they can buy it from the rental car company.

In contrast to the strategies of zero-solutions and system solutions, which are corporate strategies, the strategies of a more intensive and a longer utilization of goods are strategies for both economic actors and individuals, i.e. they are open to monetary and non-monetary applications. A number of people sharing in the utilization of a pool of goods can draw the same utilization value through a more intensive utilization of a substantially reduced number of goods, thus achieving a higher resource productivity per unit of service. Examples for this are, besides public infrastructures such as lighthouses, roads, concert halls and railway systems, the Lufthansa car pool for flight crews, car sharing cooperatives in Europe, car pooling in US companies.

Examples for a longer utilization of goods through repairs, remanufacturing and technical upgrading are the retreading of tyres, the elevator business, and remanufacturing activities in general - which are highly developed in North America, but neglected in most European countries. Long-term quality warranty for components becomes a key factor in turning longer service-life of goods into a profitable business. The problems with cheaper clone components of inferior quality (and often with fake quality certificates) in e.g. aircraft maintenance occasionally hit the headline news - but the origins of the problem are linked to the strategy of the Industrial Economy to sell goods with a short-term warranty, and a lack of incentives for long-term manufacturer stewardship. If, however, production and ownership, as well as the responsibility for operation and maintenance, remain in the hands of one company (the manufacturer cum fleet operator), there is no incentive to use cheaper components for economic reasons, and less quality doubts arise in reusing own components of known quality in new goods. Xerox Corp. is probably the best example for the successful application of such a corporate strategy of the service economy.

Insurance is already a major promoter of product-life extension, e.g. in the case of cars and electronic goods. There is a great potential of regional insurance knowledge (and savings) that is not yet applied by insurers in other regions. In car repairs, the application of the utilization value (the central notion of value in the service economy) instead of the usual depreciation value favours the repair of damaged cars over their replacement. Belgium law, to quote one example, gives the owner of a damaged vehicle the right to insist on a physical replacement instead of the payment of a (often symbolic) sum of money - never mind the age of the car. In Scandinavia, the development by insurance of dedicated technologies to repair plastic car bumpers has resulted in cost savings to insurers as well as in reduced waste volumes (and thus a higher resource productivity). With regard to electronic goods, the availability of "new value" insurance in Europe has led to a sophisticated industry of loss mitigation (salvaging and remanufacturing of electronic goods after fires or floods), which works almost exclusively for insurance companies and will intervene immediately after a fire (see Risk Manager, no. 43/1997).

In all these cases, local repair workshops create job opportunities (Stahel/Reday, 1976/1981) and know-how that would often not exist without insurers - and local job creation is a central issue in "social ecology" (chapter 5). The lack of social ecology can have a strong negative influence on insurance, through e.g. the phenomenon of moral 
hazard. This was the case of the "new value" insurance for yachts in the Netherlands, which had to be discontinued when a recession convinced people to "cash in" on the higher value by "accidentally" sinking their yachts, rather than sell their boats on the depressed market.

Insurance could also be a strong promoter of schemes in which consumer groups share or lend/borrow goods between themselves. According to a recent study in Germany, the main obstacle to a general application of these strategies is the absence of "group insurance", which exists for commercial groups (e.g. agricultural machinery) but not for groups of individuals. The element of "sharing" goes hand in hand with caring and is part of social ecology, which is a precondition for a sustainable society and also of a high selfinterest for insurance.

\section{Insurance's self-interest in the fight for sustainability}

When society evolves down the "sustainability pillars" from "resource productivity" to "social and cultural ecology" (see Box 3), a second ceasure occurs touching at the very foundation of insurance. Whenever the social and cultural ecology breaks down, in extreme cases during civil wars, the very basis of the vision of a sustainable society is destroyed, as the first three pillars of nature conservation, human health and safety and resource productivity go up in smoke - and insurers lose their business.

The signs have been on the wall for quite some time. To quote but one example: speed limits are a strategy of risk limitation which is highly efficient both ecologically and safety wise. But few people stick to speed limits because of conviction - rather out of fear to be fined by the police. The fact that most people disobey speed limits regularly shows that many rules of society are no longer respected even by decent people. This effects many other issues in society. Insurers could, of course, refuse to pay damages for cars that were driven above the speed limit. In Germany, there have been two recent cases on this issue that went all the way to the Federal Court. And the Federal Court confirmed the right of an insurer to refuse the payment of damages only on the grounds of excess speed (as Germany does not have a general speed limit on motorways, the Court stated that insurance is only liable up to the speed limit of $120 \mathrm{~km} / \mathrm{h}$ recommended by the Government). Driving above this speed increasingly engages the liability of the driver - at $200 \mathrm{~km} / \mathrm{h}$, insurance need no longer apply. But even in Germany, most people ignore these court decisions, and nobody seems to have an interest to make them public knowledge. Bringing this information to the knowledge of the public at large might give insurers a bad image, but would certainly be a strong deterrent against speeding and thus help to prevent accidents! Pushing sustainability may show insurers that they also have two souls in their chest.

That education can work within a closed system has been shown very successfully by the German "Berufsgenossenschaften", insurance pools that are specific to each profession and based on the peer system. After accidents, the causes are analyzed and corrected. In an open system, such as the commercial navy, education is difficult to control: according to a recent report, many crews are frequently unable to read manuals or make entries in log books because the language used is unknown to them. Engine room damage, which is especially vulnerable to this phenomenon, accounted for $35 \%$ of marine insurance claims last year. 
In many countries all over the world, the social fabric looks increasingly vulnerable: neglect, crime, vandalism, terrorism and war are the most visible signs of it. Furthermore, modern technology has consistently been developed by coupling higher productivity with higher vulnerability, and by creating interlinked systems which contain anonymous risk multipliers; the latest example are computer networks. These systems rely on a socially responsible behaviour of people. Alternative options, e.g. to increase fault tolerance or reduce vulnerability, are in many cases ignored.

According to a recent report in Post Magazine, "London City insurer Nordstern has called for industry-wide support for its bid to stop "Rolex raiders" by making policyholders more streetwise. The company's advice to clients includes wearing cheap watches or even costume jewellery for everyday wear, and trying to avoid wearing expensive items with a short sleeved blouse or sleeveless dress. It also called on policyholders to carry a portable alarm, to watch where they park their car, discourage house to house callers and telephone enquiries, as well as resist the temptation to appear with jewellery in glossy magazines" (Post Magazine, 1997). In the USA, the construction industry's biggest contracts today are "gated communities", i.e. cities for the rich that are closed off from the real world by walls and gates with security guards.

But the socially excluded are discovering the vulnerability of "public systems": throwing stones from motorway bridges onto cars, or cables onto railway lines, or setting fire to parked cars in dark streets, has become a "normal" pastime in many areas of socalled developed countries; "senseless" drive-by shootings do not only happen in Los Angeles any more; and the German opponents to nuclear power have picked the German Railways as an ideal victim: while 20 '000 police protected, during seven days, the transport of a few "Castor" containers filled with nuclear waste to a temporary waste dump at Gorleben, the opponents, in a concerted action, paralyzed all trains for half a day in the Berlin region - at the other end of Germany. The cost of the police protection of the nuclear waste amounts to several tens of millions of DM, the cost to the German railway could be the same; in both cases, insurance is not (yet) involved - but government offices go to war against each other on which one has to pay for the protection.

The question arises therefore if modern society, based on legal frameworks and penal systems (i.e. command and control), can find a recipe for sustainability in areas where precaution, based on socio-cultural values, is the only strategy (such as preserving the global commons, which include the $\mathrm{CO}_{2}$-issue of global warming), without falling victim to "the prisoners' dilemma" (where each individual fares better than his or her inmates by ruthlessly exploiting his or her personal advantage, but where the prisoners as a whole are better off by cooperating with each other).

The latest Sigma report states that $64.1 \%$ of all insured losses in 1996 were caused by "natural" catastrophes, the rest being "man-made" disasters. $50 \%$ of the latter are due to "major fires, explosions" (including two cases of arson and one bomb attack). This means that $20 \%$ of all losses are already due to terrorism and social unrest! (Sigma 3/1997) (box 5).

There are several reasons while the breakdown of "social ecology" and its consequences are not yet visible or not known to most people, be they politicians, technical experts or the man or woman in the street: 
Box 5 : List of major losses in 1996 worldwide

\begin{tabular}{|c|c|c|c|}
\hline & $\begin{array}{l}\text { no. } \\
\text { losses }\end{array}$ & $\begin{array}{l}\text { no. } \\
\text { victims }\end{array}$ & $\begin{array}{l}\text { insured } \\
\text { losses }\end{array}$ \\
\hline Total & 341 & $100 \%$ & $100 \%$ \\
\hline Natural catastrophes & 129 & $62,8 \%$ & $64,1 \%$ \\
\hline $\begin{array}{l}\text { Man-made disasters } 1 \\
\text { of which }\end{array}$ & 212 & $37,2 \%$ & $35,9 \%$ \\
\hline major fires explosions & 37 & $2,7 \%$ & $17,0 \%$ \\
\hline terrorism, social unrest & 19 & $3,8 \%$ & $7,6 \%$ \\
\hline
\end{tabular}

${ }^{1}$ incl. 2 major arson and one bomb attack

Source: Swiss Re, sigma no. 3/1997

a) Most people are unaware of the fact that on a philosophical level, a modern NationState is based on several monopolies, of which the "monopoly of violence" is not the least (see Max Weber's publications for more details)! The growing appearance of private security forces (e.g. black sheriffs in Europe), bodyguards and the general armament of the population "to feel secure" is a clear indication of societal breakdown.

The economic competitiveness of whole economic sectors may even be based on breaking the law: haulage companies are competitive with the railways partly because the laws on working time, speed and weight limits are not obeyed - the watchdog function of the railway unions does not exist on the road, and independent ownerdrivers are easily victims of self-exploitation. The police has only little might against the solidarity of the lorry drivers and their $\mathrm{CB}$ radios.

b) "Becoming rich" used to be an opportunity within the reach of every hard working person: the American dream of a shoe cleaner becoming a millionaire was a reality! Today, wealth is increasingly linked to knowledge and money, no longer to human labour and manual skills - and thus excludes most people who are not rich, or do not have a sellable knowledge in a domain of the future. Many individuals thus feel excluded from the benefits of society, and no longer feel obliged to contribute to, or respect the values of, society as a whole.

c) On a perception level, there is a fundamental difference between the "outlaws" of the past and the "out-of-society" people of today: out-laws were put outside society by the law, and were therefore known to society; "clochards" lived their alternative life openly and peacefully. The modern "out-of-society" people, however, are often unknown to society, or only known after their first act of despair or madness. The pattern of risk created by these people is random, the timing unforeseeable, the number unknown, the maximum loss catastrophic (e.g. Federal building in Minneapolis).

The people outside society include unemployed and working poor with an increasing number of families with children. Many of these people cannot afford medical insurance, some live in the street or in homes, and most have in common that they are 
outside the reach of (preventive) medicine. These "out-of-society" people are largely responsible for spreading the old (once eradicated) infectious diseases, such as tuberculosis, in Western countries.

d) On a societal level, another slow but potentially disastrous change is taking place (Miegel, 1997): the supporting role of "collectives" (family, church) has, at least in Europe, given way to individualism combined with State security nets. Unemployment benefits, social welfare for single parent families and other State support systems have replaced the previous private safety nets - at a considerable monetary cost to the State, financed through higher taxes. The unfortunate combination of an economic recession and the increased demand for State support has led to the financial crisis of the modern social welfare State in e.g. Germany. If due to the shrinking tax income (combined with the Maastricht-criteria) the State is forced to reduce its expenditures, many of the people surviving on State welfare might become people "outside society", "economic out-laws".

\section{Conclusion}

The common denominator of sustainability and insurance is the need for a stable social fabric within a long-term vision.

Today, insurance has the opportunity to use its specific know-how in order to foster and speed up new industrial and public policies that lead to a higher sustainability and a higher competitiveness of national economies. At the same time, this reinforces the social fabric of society which is at the foundation of insurance business.

Insurance will have to actively seize this new role, as it will influence the existing power structure. A "commitment to promote innovation" between industry, the State and the insurance sector could bring about a fast paradigm shift towards a more sustainable society. 


\section{LITERATURE AND SOURCES}

Carnoules Declaration of the Factor 10 Club (1994); available from Prof. Dr F. Schmidt-Bleek, VicePresident, Wuppertal Institute, D-42103 Wuppertal.

COOMER, James C. (ed.) (1981) Quest for a Sustainable Society, published in cooperation with The Woodlands Conference; Pergamon Press, New York, Oxford etc; ISBN 0-08-027168-5.

DIEREN, Wouter van (1995) Taking Nature into account, Birkhäuser-Verlag, Basel, ISBN 3-76435173-X.

GIARINI, Orio (1997) Economics, Globalisation and insurance; information letter of the Geneva Association, no. 152, Aug 18, 1997.

GIARINI, Orio and STAHEL, Walter R. (1989/1993) The Limits to Certainty, facing risks in the new Service Economy; Kluwer Academic Publishers, Dordrecht, Boston, London - ISBN 0-7923-2167-7.

GROSS (1995), Die Multi-Options-Gesellschaft (the multi-option society), Suhrkamp Verlag.

GRUHLER, Wolfram (1990) Dienstleistungsbestimmter Strukturwandel in deutschen Industrieunternehmen; Deutscher Instituts Verlag Köln; ISBN 3-602-24406-7.

LÜBBE, Hermann (1997) Sicherheit; über Gründe schwindender Risikoakzeptanz; in: Studien zur Sicherheitspolitik 1/1995, Bern.

MIEGEL, Meinhard, Leipzig university (1997) Der wuchernde Staat als Folge eines falschen Individualismus; in: NZZ 29.-30. 3. 1997, p.79.

Post Magazine, 21 August 1997, "Bid to call time on 'Rolex raiders", p. 56.

Risk Manager, August 1997, "Sanieren billiger als Neuanschaffung", newsletter published by EAGenerali, Nr. 43. 8. Jahrgang.

SCHMIDT-BLEEK, Friedrich (1994/96) The Fossil Makers - Factor 10 and more (Wieviel Umwelt braucht der Mensch? MIPS - Das Mass für ökologisches Wirtschaften); Birkhäuser Verlags AG, Berlin, Basel; ISBN 3-7643-2959-9.

Swiss Reinsurance Company (1997) Sigma, no 3/1997.

STAHEL, Walter R. and Reday, Geneviève (1976/1981) Jobs for tomorrow, the potential for substituting manpower for energy; report to the European Commission, Brussels; Vantage Press, New York NY.

STAHEL, Walter R.

(1995) 300 examples of higher resource productivity in today's industry and society (Intelligente Produktionsweisen und Nutzungskonzepte) - Handbuch Abfall 1 - Allg. Kreislauf- und Rückstandswirtschaft; Band 1 und 2, Landesanstalt für Umweltschutz Baden-Württemberg (Hrsg.), Karlsruhe.

(1994) The impact of shortening (or lengthening) of life-time of products and production equipment on industrial competitivenes, sustainability and employment; report to the European Commission, DG III, Nov 1, 1994.

(1992) Reuse And Recycling, Waste prevention and resource savings in utilization, conference manuscript, Guildford

(1985) Hidden innovation, $R \& D$ in a sustainable society, in: Science \& Public Policy, Journal of the International Science Policy Foundation, London; Volume 13, Number, 4 August 1986: Special Issue: The Hidden Wealth.

(1984) "The Product-Life Factor"; in: Orr, Susan Grinton (ed.) An Inquiry into the Nature of Sustainable Societies: The Role of the Private Sector; HARC, The Woodlands, TX. 